\title{
МЕТАБОЛИЧЕСКИЙ СТАТУС И МОЛОЧНАЯ ПРОДУКТИВНОСТЬ КОРОВ ПРИ ПРИМЕНЕНИИ ТКАНЕВОГО БИОСТИМУЛЯТОРА ИЗ ОТХОДОВ УБОЯ ПАНТОВЫХ ОЛЕНЕЙ
}

\author{
И.А. ПУШКАРЕВ $1{ }^{\otimes}$, А.И. АФАНАСЬЕВА ${ }^{2}$, Т.В. КУРЕНИНОВА ${ }^{1}$, \\ Н.В. ШАНЬШИН 1 , Ю.А. ХАПЕРСКИЙ 1 , О.Е. МАЛЬЦЕВА ${ }^{2}$, С.В. БУРЦЕВА 2 , \\ Ю.А. ЧЕКУНКОВА ${ }^{1}$
}

Интенсивность и направленность обмена веществ в период лактации во многом определяют молочную продуктивность коров. Тканевые биостимуляторы оптимизируют обменные процессы посредством активации нейрогуморальных механизмов регуляции и положительно влияют на лактогенез и лактопоэз. Биоактивные препараты получают из разнообразного сырья с применением различных технологий. В представленном исследовании впервые установлено, что новый тканевой биостимулятор на основе вторичных продуктов оленеводства при 4-кратном введении в сухостойный период и в период раздоя положительно влияет на белковый и липидный обмен у лактирующих коров. Доказано, что применение этого биостимулятора по предлагаемой нами схеме приводит к росту суточных удоев молока, выходу молочного белка и жира за первые 60 сут лактации. Цель работы заключалась в оценке влияния разработанного тканевого биостимулятора, изготовленного из боенских отходов пантовых оленей, на показатели метаболизма и молочную продуктивность коров. Исследования проводили на коровах (Bos taurus taurus) приобского типа черно-пестрой породы в период сухостоя и начала лактации (АО Учхоз «Пригородное», г. Барнаул, Алтайский край, 2019 год). Сформировали две группы $(n=10)$ сухостойных коров-аналогов в возрасте III лактации и старше за 55-60 сут до предполагаемого отела. Коровам контрольной группы вводили физиологический раствор: в период сухостоя - за 55-60 сут до предполагаемого отела 4-кратно в дозе 22,5 мл/гол. с интервалом 14 сут; в период раздоя - с 15-х сут лактации в той же дозе и кратности. Животным опытной группы вводили тканевый биостимулятор по аналогичной схеме. Опытная партия тканевого биостимулятора была изготовлена из субпродуктов и боенских отходов пантовых оленей (А.С. РФ № 2682641). Материалом для приготовления препарата служили мезентериальные лимфоузлы и средостения, селезенка, печень, матки с плодами (23 мес), плацента, отобранные в асептических условиях во время убоя здоровых особей. При постановке коров на опыт, а также на 15-е и 60-е сут лактации брали кровь из хвостовой вены в вакуумные пробирки (с активатором сгустка). Содержание общего белка, альбуминов, холестерина, триглицеридов, глюкозы определяли на автоматическом биохимическом анализаторе ChemWell Combo 2910 («Awareness Technology, Inc.», США), количество глобулинов, альбумин-глобулиновый коэффициент и соотношение холестерина к триглицеридам - расчетным методом. Суточный удой молока учитывали на 15-е, 30-е и 60-е сут лактации контрольной дойкой, надой молока за 60 сут лактации - расчетным методом. Пробы молока отбирали на 15-е и 60-е сут лактации. Содержание в молоке белка и жира определяли на анализаторе MilkoScan FT 120 («Foss Electric», Дания), выход молочного белка и жира за 60 сут лактации - расчетным методом по общепринятой формуле. Введение тканевого биостимулятора способствовало активации метаболизма и повышению показателей пластического и энергетического обмена относительно контроля: содержания в сыворотке крови общего белка, альбуминов и холестерина - соответственно на $3,0-6,4(p<0,01)$, 9,2-6,9 (p < 0,001) и 18,3-26,0\% (p < 0,01), альбумино-глобулинового коэффициента - на 9,0$11,1 \%(p<0,01)$. На 60-е сут лактации в сравнении с 15-ми сут концентрация общего белка в сыворотке крови у коров из контрольной и опытной групп увеличилась соответственно на 9,7\% $(\mathbf{p}<0,001)$ и 6,1\% (р< 0,001), глобулинов - на 20,5\% (р<0,001) и 16,2\% (p< 0,001), холестерина на $2,0 \%$ и 8,6 \% (p < 0,01). Альбумин-глобулиновый коэффициент стал меньше на $18,2 \%(\mathrm{p}<0,001)$ и $16,7 \%(\mathrm{p}<0,001)$. Молочная продуктивность за 60 сут лактации у коров опытных групп увеличилась на $19,3 \%$ (р < 0,01), выход молочного белка и жира - на 26,7 $(\mathbf{p}<0,05)$ и $22,1 \%(\mathrm{p}<0,05)$.

Ключевые слова: тканевой биостимулятор, коровы, метаболизм, качество молока, молочная продуктивность.

Лактация сопровождается сильным функциональным напряжением организма (1). Интенсивность и направленность метаболизма у лактирующих животных связаны с молочной продуктивностью и активным сорбированием молочной железой метаболитов крови, активацией ферментов, 
участвующих в процессах лактогенеза, перераспределением субстратных потоков для обеспечения лактационной функции (2). Развитие лактационного процесса должно обеспечиваться высокой активностью желез внутренней секреции, принимающих непосредственное участие в синтезе предшественников компонентов молока $(3,4)$.

Биостимуляторы - это биологически активные препараты, способные повышать естественную резистентность, устойчивость к стрессам, воздействовать на ферментные и другие процессы, тем самым увеличивая количественные и качественные показатели продуктивности (5-8). В последнее десятилетие наблюдается огромный спрос на применение биостимуляторов как в растениеводстве, так и в животноводстве, поскольку они безвредны, не вызывают привыкания и создают в благоприятные условия для проявления собственных защитных реакций организма $(5,7,9,10)$. Биостимуляторы можно получать из разнообразного биоорганического сырья, следовательно, не существует единого механизма их влияния на организм $(7,11-13)$.

К классу биостимуляторов природного происхождения относят тканевые препараты (14-17). Они благоприятно влияют на обмен веществ, в частности увеличивается количество общего белка, альбуминов, билирубина, мочевины, холестерина, повышается активность ферментов переаминирования аланинаминотрансферазы и аспартатаминотрансферазы, обладая антиоксидантными свойствами (16), предотвращают перекисное окисление липидов $(15,18-20)$. При применении биостимуляторов существенно повышается естественная резистентность за счет увеличения лизоцимной и бактерицидной активности сыворотки крови, функциональной активности нейтрофилов, увеличения содержания в крови Т- и В-лимфоцитов (2123). Использование тканевых препаратов способствует интенсивному росту молодняка сельскохозяйственных животных при откорме $(19,24)$, молочной продуктивности и воспроизводительных качеств коров, сохранности молодняка (9).

В представленной работе впервые установлено, что применение нового тканевого биостимулятора по разработанной схеме (4-кратное введение нового тканевого биостимулятора коровам в сухостое и в период раздоя) активирует белковый и липидный обмен, приводит к росту суточных удоев и выхода молочного белка и жира за первые 60 сут лактации.

Цель исследований заключалась в оценке влияния тканевого биостимулятора, изготовленного из боенских отходов пантовых оленей, на показатели метаболизма и молочную продуктивность коров.

Методика. Исследования проводили на коровах (Bos taurus taurus) приобского типа черно-пестрой породы в период сухостоя и начала лактации (АО Учхоз «Пригородное», г. Барнаул, Алтайский край, 2019 год). Сформировали две группы ( $n=10$ в каждой) сухостойных коров-аналогов в возрасте III лактации и старше за 55-60 сут до предполагаемого отела. Животных подбирали с учетом их молочной продуктивности, предшествовавшей сухостойному периоду (среднесуточный удой по последней контрольной дойке перед запуском - 22,5 л), и живой массы (550 кг). Упитанность животных на начало опыта составляла 3,2 балла.

Коровам из контрольной группы вводили физиологический раствор в два этапа: в период сухостоя - за 55-60 сут до предполагаемого отела 4-кратно в дозе 22,5 мл/гол. с интервалом 14 сут; в период раздоя с 15-х сут лактации в той же дозе и кратности. Животным опытной группы вводили тканевый биостимулятор по аналогичной схеме. 
Опытная партия тканевого биостимулятора была изготовлена из субпродуктов и боенских отходов пантовых оленей (Шаньшин Н.В., Евсеева Т.П. Способ производства биогенных препаратов. А.с. 2682641 (РФ) МКИ А 61К 35/12. ФАНЦА (РФ). № 2698707 C1. 2019). Материалом для приготовления препарата служили мезентериальные лимфоузлы и средостения, селезенка, печень, матки с плодами (2-3 мес), плацента, отобранные в асептических условиях во время убоя здоровых животных. Полученный нативный материал помещали в холодильник на 6 сут при $2-4{ }^{\circ} \mathrm{C}$. По истечению указанного срока весь материал в равных частях измельчали и помещали в ультразвуковую установку Elmasonic P («Elma Schmidbauer $\mathrm{GmbH»,} \mathrm{Германия).} \mathrm{Контроль} \mathrm{качества} \mathrm{на} \mathrm{токсичность} \mathrm{и} \mathrm{реактогенность}$ проводили на белых мышах (ГОСТ 31926-2013. Средства лекарственные для ветеринарного применения. Методы определения безвредности. М., 2014).

При постановке коров на опыт, а также на 15-е и 60-е сут лактации брали кровь из хвостовой вены в вакуумные пробирки (с активатором сгустка). Содержание общего белка, альбуминов, холестерина, триглицеридов, глюкозы определяли на автоматическом биохимическом анализаторе ChemWell Combo 2910 («Awareness Technology, Inc.», США), количество глобулинов, альбумин-глобулиновый коэффициент и соотношение холестерина к триглицеридам - расчетным методом.

Суточный удой молока учитывали на 15-е, 30-е и 60-е сут лактации контрольной дойкой, надой молока за 60 сут лактации - расчетным методом. Пробы молока для лабораторных исследований отбирали на 15 -е и 60-е сут лактации. Содержание в молоке белка и жира определяли на прибope MilkoScan FT 120 («Foss Electric, Дания), выход молочного белка и жира за 60 сут лактации - расчетным методом по общепринятой формуле.

Полученные данные подвергали биометрической обработке при помощи программного пакета Microsoft Excel 2016, вычисляли среднеарифметические значения $(M)$, среднеквадратические ошибки ( \pm MSE) и критерий достоверности (p). Достоверность результатов опыта по отношению к контрольной группе рассчитывали по $t$-критерию Стьюдента для независимых выборок, статистически значимыми считали различия при $\mathrm{p}<0,05$; $\mathrm{p}<0,01$; $\mathrm{p}<0,001$. Значения биохимических показателей крови коров на 60 -е сут лактации в сравнении с 15-ми сут по $t$-критерию Стьюдента для зависимых выборок считали статистически значимыми при $\mathrm{p}<0,05$; $\mathrm{p}<0,01$; $\mathrm{p}<0,001$.

Результаты. Биохимические показатели крови коров до введения препарата соответствовали физиологическим значениям у беременных (во время сухостойного периода) и лактирующих животных (сразу после отела) и существенно не различались в контрольной и опытной группах (табл. 1).

1. Биохимический состав сыворотки крови у коров (Bos taurus taurus) приобского типа черно-пестрой породы на 15-е и 60-е сут лактации при использовании тканевого биостимулятора из боенских отходов пантовых оленей $(n=5$, $M \pm \mathrm{MSE} ; \mathrm{AO}$ «Учхоз «Пригородное», г. Барнаул, Алтайский край, 2019 год)

\begin{tabular}{|c|c|c|c|c|c|}
\hline \multirow{2}{*}{ Показатель } & \multicolumn{4}{|c|}{ Группа } & \multirow{2}{*}{$\begin{array}{l}\text { Норма } \\
(25-27)\end{array}$} \\
\hline & контрольная & фон & опытная & фон & \\
\hline Общий белок, г/л & $\frac{72,9 \pm 0,83}{80,0 \pm 0,54}$ & $73,7 \pm 3,35$ & $\frac{77,6 \pm 0,62^{* *}}{82,4 \pm 0,81^{*} \Delta \Delta \Delta}$ & $76,3 \pm 1,62$ & $72,0-86,0$ \\
\hline Альбумины, г/л & $\frac{38,9 \pm 0,56}{39,0 \pm 0,41}$ & $39,9 \pm 0,70$ & $\frac{42,5 \pm 0,22^{* * *}}{41,7 \pm 0,41^{* * *}}$ & $37,9 \pm 2,15$ & $38,0-50,0$ \\
\hline Глобулины, г/л & $\frac{34,0 \pm 0,49}{41,0 \pm 0,34^{\Delta \Lambda \Delta}}$ & $33,9 \pm 2,38$ & $\frac{35,1 \pm 0,59}{40,8 \pm 0,75^{\Delta \Delta \Delta}}$ & $38,4 \pm 2,31$ & $34,0-36,0$ \\
\hline Соотношение А/Г, ед. & $\frac{1,1 \pm 0,02}{0,9 \pm 0,01^{\Delta \Delta \Delta}}$ & $1,2 \pm 0,09$ & $\frac{1,2 \pm 0,02^{*}}{1,0 \pm 0,02^{* * \Delta \Delta \Delta}}$ & $1,0 \pm 0,11$ & $0,6-1,3$ \\
\hline Холестерин, ммоль/л & $\frac{4,9 \pm 0,13}{5,0 \pm 0,24}$ & $5,6 \pm 0,15$ & $\frac{5,8 \pm 0,20^{* *}}{6,3 \pm 0,21^{* * \Delta \Delta}}$ & $5,1 \pm 0,44$ & $2,3-6,6$ \\
\hline
\end{tabular}


уменьшается в сравнении с началом лактации (33). Метаболические изменения такого характера могут быть связаны с тем что, в период ранней лактации резко возрастает потребность животных в энергии, жировые резервы организма сокращаются, повышается нагрузка на печень, и ее функциональная активность снижается (34).

Тканевые биостимулятопры на основе плаценты содержат факторы роста гепатоцитов печени (HGF) $(35,36)$, в которых происходит синтез протеинов из аминокислот, что, возможно, объясняет более интенсивный белковый обмен у коров из опытной группы. Ткани печени, селезенки, лимфоузлов и матки с плодами, входящие в состав биостимулятора, содержат нативное сочетание витаминов, аминокислот и минеральных веществ, обеспечивающих оптимальные условия для улучшения обменных процессов в печени (37). В частности, витамины обладают гепатопротекторным эффектом, способствуют регенерации гепатоцитов, препятствуют избыточному производству коллагена звездчатыми клетками, снижают окислительный стресс печени и предупреждают развитие фиброза (38). Микроэлементы повышают функциональную активность печени, ее адаптационные свойства, препятствуют разрушению гепатоцитов, способствуют накоплению в них гликогена (39). Такие незаменимые аминокислоты, как цистеин и метионин, служат предшественниками липотропного вещества холина, которое препятствует жировому перерождению печени (40). На усиление регенеративных и метаболических процессов в печени, а также иммунных функций при применении биогенных стимуляторов указывают исследования других авторов $(35,41-43)$. Повышение количества общего белка и альбуминов в сыворотке крови лактирующих коров при применении тканевых препаратов отмечали в аналогичных исследованиях $(44,45)$.

Известно, что содержание холестерина в крови у здоровых животных находится в прямой корреляционной зависимости с показателями их молочной продуктивности $(29,46)$. Применение тканевого биостимулятора приводило к повышению количества холестерина в сыворотке крови у коров опытной группы на 15-е и 60 -е сут лактации на 18,3 и 26,0 \% (p < 0,01) в сравнении с контролем. Наши данные согласуются с результатами, представленными в ранее опубликованных работах (47). Более высокое содержание холестерина у лактирующих животных из опытной группы способствовало повышению их молочной продуктивности, поскольку известно об участии холестерина в процессах обновления мембранных липидов молочной железы, что приводит к увеличению количества железистой ткани в молочной железе $(29,48)$. В исследованиях ряда авторов установлено, что активация жирового, углеводного и белкового обмена в период лактации, способствующая пролиферации клеток железистой ткани молочной железы (49) и ее росту $(48,50)$, может происходить за счет биологически активных веществ, находящихся в экстракте плаценты (48).

Применение тканевого препарата не оказало существенного воздействия на количество триглицеридов у животных опытной группы. В то же время соотношение холестерина к триглицеридам в сыворотке крови у коров опытной группы на 15 -е и 60 -е сут лактации оказалось соответственно на 3,5 и 47,9\% (p < 0,05) больше, чем в контроле, что указывает на усиление энергетических затрат, в том числе на использование глюкозы как источника энергии (26). В первые дни лактации молочная железа становится основным потребителем глюкозы, в связи с этим ее количество в сыворотке крови снижается (51). В нашем эксперименте в крови животных из контрольной и опытной групп также установлены более низкие показатели по глюкозе на 15-е сут лактации и их повышение на 13,3 и 23,0 \% (p < 0,05) 
к 60-м сут.

Степень и направленность обмена веществ оказывали значительное влияние на показатели молочной продуктивности животных (табл. 2). При подкожном введении тканевого биостимулятора в дозе 22,5 мл/гол. суточные удои повышались на 15-е, 30-е и 60-е сут лактации соответственно на $21,0(\mathrm{p}<0,01), 18,9(\mathrm{p}<0,05)$ и $18,6 \%(\mathrm{p}<0,05)$ в сравнении с контрольной группой. За 60 сут лактации от животных из опытной группы получили на $32,0 \%$ ( $<0,01)$ больше молока, чем в контроле.

Увеличение суточных удоев молока в опытной группе сопровождалось незначительным снижением содержания белка и жира - на 0,1 и 0,4 \% ( $>$ < 0,05) относительно контроля. Однако выход молочного белка и жира за 60 сут лактации за счет количественных показателей удоя у коров из опытной группы стал больше на 26,7 (p<0,05) и 22,1\% (p < 0,05).

2. Молочная продуктивность коров (Bos taurus taurus) приобского типа чернопестрой породы при использовании тканевого биостимулятора из боенских отходов пантовых оленей $(n=10, M \pm \mathrm{MSE}$; АО Учхоз «Пригородное», г. Барнаул, Алтайский край, 2019 год)

\begin{tabular}{l|c|c}
\hline \multicolumn{1}{c|}{ Показатель } & \multicolumn{2}{c}{ Группа } \\
\cline { 2 - 3 } Суточный удой, л: & контрольная & опытная \\
на 15-е сут & $33,3 \pm 0,75$ & $40,3 \pm 1,99^{* *}$ \\
на 30-е сут & $34,9 \pm 1,67$ & $41,5 \pm 2,05^{*}$ \\
на 60-е сут & $35,3 \pm 0,89$ & $41,9 \pm 2,03^{*}$ \\
Получено молока за 60 сут, л & $2002,0 \pm 113,95$ & $2644,0 \pm 57,76^{* *}$ \\
Содержание белка в 1 л, \% & $3,1 \pm 0,07$ & $3,0 \pm 0,17$ \\
Выход молочного белка за 60 сут лактации, кг & $63,5 \pm 4,28$ & $80,5 \pm 3,58^{*}$ \\
Содержание жира в 1 л, \% & $4,5 \pm 0,09$ & $4,1 \pm 0,08^{*}$ \\
Выход молочного жира за 60 сут лактации, кг & $92,0 \pm 4,95$ & $112,4 \pm 4,32^{*}$ \\
П и м е ч а н и е. Описание групп см. в разделе «Методика». & \\
*, ** Различия с контролем статистически значимы соответственно при р < 0,05 и р $<0,01$. \\
\hline
\end{tabular}

Повышение молочной продуктивности сельскохозяйственных животных при применении тканевых препаратов установлено и другими авторами $(14,52,53)$. Действующим началом тканевых биостимуляторов, по мнению академика В.П. Филатова, служат вещества, вырабатываемые клетками в процессе жизнедеятельности в крайне неблагоприятных условиях, которые он назвал биогенными (54). К ним относят комплекс органических карбоновых кислот, соединения типа альбуминов и пептонов - крупные белковые фрагменты неполного гидролиза белков, которые оказывают общее стимулирующее действие на организм, активно участвуют в физиологических процессах в тканях и органах. В механизме действия тканевых препаратов ведущая роль отводится нервно-гуморальной и гуморальной системе, основу которых составляет центральная нервная система и гипоталамо-гипофизарный комплекс. Установлено, что в изменении сопротивляемости организма к внешним воздействиям основная роль принадлежит нервной системе, ее адаптационно-трофической функции. Гипоталамо-гипофизарный комплекс регулирует нейроэндокринную деятельность и поддерживает гомеостаз (14).

В период ранней лактации коров катаболический характер обмена веществ приводит к изменению и перераспределению основных метаболических потоков на процессы лактогенеза и лактопоэза (55). Возникает необходимость в активации метаболизма, что может быть достигнуто за счет применения тканевых биостимуляторов. Происходит преобразование сигналов от механических, химических и других раздражителей в сигналы, непосредственно связанные с центральной нервной системой и всеми звеньями нейрогуморального аппарата, что обусловливает разнообразие воз- 
действия тканевых биостимуляторов на различные физиологические системы организма (56).

В нашем эксперименте применение тканевого биостимулятора привело к увеличению концентрации в сыворотке крови коров общего белка, альбуминов, повышению альбумин-глобулинового коэффициента и уровня холестерина. Активация белкового и энергетического обмена ведет к усилению секреторной функции эпителия молочной железы, что выражается в росте молочной продуктивности (57).

Таким образом, введение тканевого биостимулятора, изготовленного из боенских отходов пантовых оленей, в дозе 22,5 мл/гол. 4-кратно с интервалом 14 сут способствовало активации метаболизма и увеличению показателей пластического и энергетического обмена у лактирующих коров приобского типа черно-пестрой породы. Содержание в сыворотке крови общего белка, альбуминов и холестерина увеличивалось относительно контроля соответственно на 3,0-6,4 (p < 0,01), 9,2-6,9 (p < 0,001) и 18,3-26,0\% $(\mathrm{p}<0,01)$ при повышении альбумино-глобулинового коэффициента на 9,0$11,1 \%(\mathrm{p}<0,01)$. Молочная продуктивность за 60 сут лактации повышалась на $19,3 \%(\mathrm{p}<0,01)$, выход молочного белка и жира - на 26,7 (p < 0,05) и $22,1 \%(\mathrm{p}<0,05)$.

\section{Л ИТ Р РАТ УРА}

1. Sayiner S., Darbaz I., Ergene O., Aslan S. Changes in antioxidant enzyme activities and metabolic parameters in dairy cows during different reproductive periods. Theriogenology, 2021, 159: 116122 (doi: 10.1016/j.theriogenology.2020.10.024).

2. Huber K., Dänicke S., Rehage J., Sauerwein H., Otto W., Rolle-Kampczyk U., von Bergen M. Metabotypes with properly functioning mitochondria and anti-inflammation predict extended productive life span in dairy cows. Scientific Reports, 2016, 6: 24642 (doi: 10.1038/srep24642).

3. Грачев И.И., Галанцев В.П. Физиология лактации сельскохозяйственных животных. М., 1974.

4. Тверской Г.Б. Регуляция секреции молока. Л., 1972.

5. Xu L., Geelen D. Developing biostimulants from agro-food and industrial by-products. Frontiers in Plant Science, 2018, 9: 1567 (doi: 10.3389/fpls.2018.01567).

6. Растоваров Е.И. Эффективность использования биологических стимуляторов в практике животноводства. Мат. Межд. науч.-практ. Интернет-конф. «Инновации и современные технологии в сельском хозяйстве». Ставрополь, 2010: 316-322.

7. Brown P., Saa S. Biostimulants in agriculture. Frontiers in Plant Science, 2015, 6: 671 (doi: 10.3389/fpls.2015.00671).

8. Smolentsev S.Yu., Korosteleva V.P., Matveeva E.L., Nurgalieva A.R., Nurgaliev F.M. Assessment of influence of biostimulating medicines on the cow milk cheeseability. IOP Conference Series: Earth and Environmental Science, 2019, 315(4): 042044 (doi: 10.1088/1755-1315/315/4/042044).

9. Pogodaev V.A., Arilov A.N., Petenko A.L., Soldatov A.A., Pakhomova T.I. Influence of the immune modulation drug PIM on the cows' metabolism and calves growth rates born from them. Research Journal of Pharmaceutical Biological and Chemical Sciences, 2018, 9(4): 755-759.

10. Khan W., Rayirath U.P., Subramanian S., Jithesh M.N., Rayorath P., Hodges D.M., Critchley A.T., Craigie J.S., Norrie J., Prithiviraj B. Seaweed extracts as biostimulants of plant growth and development. Journal of Plant Growth Regulation, 2009, 28: 386-399 (doi: 10.1007/s00344009-9103-x).

11. Rose M.T., Patti A.F., Little K.R., Brown A.L., Jackson W.R., Cavagnaro T.R. Chapter two A meta-analysis and review of plant-growth response to humic substances: practical implications for agriculture. Advances in Agronomy, 2014, 124: 37-89 (doi: 10.1016/B978-0-12-8001387.00002-4).

12. Calvo P., Nelson L., Kloepper J.W. Agricultural uses of plant biostimulants. Plant and Soil, 2014, 383: 3-41 (doi: 10.1007/s11104-014-2131-8).

13. Alibardi L., Mlitz V., Eckhart L. Immunolocalization of scaffoldin, a trichohyalin-like protein, in the epidermis of the chicken embryo. The Anatomical Record, 2015, 298(2): 479-487 (doi: 10.1002/ar.23039).

14. Рубинский И., Петрова О.Г. Иммунные стимуляторы в ветеринарии. Ульяновск, 2011. 
15. Цыганский Р.А. Сравнительное действие токоферола и тканевого препарата БСМ на интенсивность процессов липопероксидации у коров айрширской породы. Ученые записки казанской государственной академии ветеринарной медицины им. Н.Э. Баумана, 2010, 202: 239-243.

16. Rzhepakovsky I.V., Timchenko L.D., Areshidze D.A., Avanesyan S.S., Budkevich E.V., Piskov S.I., Mannino S., Lodygin A.D., Kovalev D.A., Kochergin S.G. Antioxidant activity of chicken embryo tissues powder obtained by different methods of hydrolysis. Journal of Hygienic Engineering and Design, 2019, 27: 125-136.

17. Chakraborty P.D., Bhattacharyya D. Aqueous extract of human placenta as a therapeutic agent. In: Recent advances in research on the human placenta /J. Zheng (ed.). InTech, 2012: 77-92 (doi: 10.5772/31669).

18. Desai S.N., Farris F.F., Ray S.D., Wexler P. Lipid peroxidation. In: Encyclopedia of toxicology. Academic Press, Oxford, 2014: 89-93 (doi: 10.1016/B978-0-12-386454-3.00327-4).

19. Pogodaev V.A., Komlatsky V.I., Komlatsky G.V., Arylov Yu.N., Nesterenko M.A. Productive and interior features of piglets when using biogenic stimulators sitr and st. Research Journal of Pharmaceutical, Biological and Chemical Sciences, 2017, 8(6): 632-637.

20. Areshidze D., Timchenko L., Rzhepakovsky I., Kozlova M., Syomin I. Influence of the tissue preparation Nika-em on morphofunctional condition of a liver of rats at norm and at experimental non-alcoholic steatohepatitis. Pharmacology Online, 2015, 2: 108-117.

21. Соколова Е.С., Еремин С.П., Яшин И.В. Иммунобиохимический гомеостаз у коров под влиянием тканевых препаратов. Вестник Нижегородской государственной сельскохозяйственной академии, 2013, 3: 441-443.

22. Кольберг Н.А. Создание и применение отечественного тканевого (органного) препарата, на внутриклеточные процессы органов и тканей опытных животных. Mam. XI Межд. науч.практ. конф. "Фундаментальные и прикладные науки сегодня». North Charleston, 2017: 1-10.

23. Li X., Su Y., Sun J., Yang Y. Chicken embryo extracts enhance spleen lymphocyte and peritoneal macrophages function. Journal of Ethnopharmacology, 2012, 144(2): 255-260 (doi: 10.1016/j.jep.2012.09.001).

24. Florescu S., Paraschiv S., Rarinca C., Stavri J. Effect of biogenic stimulants in the early fattening of young sheep. Lucrarile Stiintifice ale Institutului de Cercetari pentru Nutritie Animala, 1975, 4: $117-130$

25. Кондрахин И.П., Архипов А.В., Левченко В.И., Таланов Г.А., Фролова Л.А., Новиков В.Э. Методы ветеринарно-клинической лабораторной диагностики: Справочник. М., 2004.

26. Мейер Д., Харви Д. Ветеринарная лабораторная медицина. Интерпретация и диагностика. M., 2007.

27. Финогенов А.Ю. Биохимические показатели крови животных в норме и при патологии: монография. Минск, 2011.

28. Linn J.G. Factors affecting the composition of milk from dairy cows. In: Designing foods: animal product options in the marketplace. National Academies Press, Washington DC, 1988: 224-241.

29. Громыко Е.В. Оценка состояния организма коров методами биохимии. Экологический вестник северного Кавказа, 2005, 1(2): 80-94.

30. Bobbo T., Fiore E., Gianesella M., Morgante M., Gallo L., Ruegg P.L., Bittante G., Cecchinato A. Variation in blood serum proteins and association with somatic cell count in dairy cattle from multi-breed herds. Animal, 2017, 11(12): 2309-2319 (doi: 10.1017/S1751731117001227).

31. Levitt D.G., Levitt M.D. Human serum albumin homeostasis: a new look at the roles of synthesis, catabolism, renal and gastrointestinal excretion, and the clinical value of serum albumin measurements. International Journal of General Medicine, 2016, 9: 229-255 (doi: 10.2147/IJGM.S102819).

32. Sun L., Yin H., Liu M., Xu G., Zhou X., Ge P., Yang H., Mao Y. Impaired albumin function: a novel potential indicator for liver function damage? Annals of Medicine, 2019, 51(7-8): 333-344 (doi: 10.1080/07853890.2019.1693056).

33. Афанасьева А.И. Физиологические механизмы адаптации коз Горноалтайской пуховой породы в постнатальном онтогенезе: монография. Барнаул, 2016.

34. Душкин Е.В. О связи между функцией молочной железы и жировой дистрофии печени у высокопродуктивных коров. Сельскохозяйственная биология, 2010, 2: 18-24.

35. Jung J., Lee H.-J., Lee J.M., Na K.-H., Hwang S.-G., Kim G.J. Placenta extract promote liver regeneration in CCI4-injured liver rat model. International Immunopharmacology, 2011, 11(8): 976-984 (doi: 10.1016/j.intimp.2011.02.012).

36. Yagi A., Ataka S. Putative prophylaxes updated of placenta extract and aloe vera as biogenic stimulants. Journal of Gastroenterology and Hepatology Research, 2014, 3(12): 1585-1598 (doi: 10.17554/j.issn.2224-3992.2014.03.443).

37. Денисенко Т.С. Фармако-токсикологические свойства димикара и его применение при гепатозах коров. Канд. дис. Ставрополь, 2018.

38. Громова О.А., Торшин И.Ю., Лисицына Е.Ю. Гепатопротекторные свойства витаминов в преконцепции и при беременности. Земский врач, 2011, 4(8): 23-28.

39. Сизова Е.А., Русакова Е.А. Минеральный состав и структурно-функциональная реорганизация печени млекопитающих на фоне различной минеральной обеспеченности рациона питания. Вестник Оренбургского государственного университета, 2010, 12(118): 27-30. 
40. Душкин Е.В. Способ лечения и профилактики гепатозов у животных. A 2385728 (RU). MПK А 61 K 35/407. Сев.-кав. науч.-иссл. ин-т животноводства (РФ). № 2008113942/13. Заявл. 20.10.2009. Опубл. 10.04.10. Бюл. № 10.

41. Дяченко О.Б., Стадницька O.I., Ференц Л.В. Вплив тканинних препаратів на показники білкового обміну та репродуктивну функцію корів різної молочної продуктивності. Передгірне та гіське землеробство і тваринництво, 2016, 59: 189-198.

42. Малкова Н.Н., Остякова М.Е., Щербинина С.А., Голайдо Н.С. Биохимический статус стельных коров на фоне применения Se-содержащего и тканевого препаратов. Известия Нижневолжского агроуниверситетского комплекса: наука и высшее образование, 2020, 3(59): 74-77 (doi: 10.32786/2071-9485-2020-03-34).

43. Shvetskiǐ A.G., Vorob'eva L.M. Effect of the nonspecific biogenic stimulators pentoxyl and mumie on metabolic processes. Voprosy Meditsinskoi Khimii, 1978, 24(1): 102-108.

44. Прус В.Н., Круть С.И. Влияние тканевых препаратов «Фетоплацентин-к» и «Трутенад-д» на течение стельности, отела, послеотельного периода и состояние новорожденных телят. Ученые записки учреждения образования «Витебская ордена «Знак почета» государственная академия ветеринарной медицины», 2016, 1: 74-77.

45. Яшин И.В. Физиологическое обоснование применения иммуностимулирующего тканевого препарата для коррекции воспроизводительной функции коров. Автореф. канд. дис. Нижний Новгород, 2010.

46. Jóźwik A., Strzałkowska N., Bagnicka E., Grzybek W., Krzyżewski J., Poławska E., Kołataj A., Horbańczuk J.O. Relationship between milk yield, stage of lactation, and some blood serum metabolic parameters of dairy cows. Czech Journal of Animal Science, 2012, 57(8): 353-360 (doi: 10.17221/6270-CJAS).

47. Gross J.J., Kessler E.C., Albrecht C., Bruckmaier R.M. Response of the cholesterol metabolism to a negative energy balance in dairy cows depends on the lactational stage. PLoS ONE, 2015, 10(6): e0121956 (doi: 10.1371/journal.pone.0121956).

48. Cotor G., Pop A., Ghita M. The effect of ovine placenta extract on mammogenesis, lactogenesis and galactopoiesis in sheep. Turkish Journal of Veterinary and Animal Sciences, 2011, 35(3): 137142 (doi: 10.3906/vet-0610-34).

49. Takahashi K., Suzuki K., Kawahara S., Ono T. Effects of lactogenic hormones on morphological development and growth of human breast epithelial cells cultivated in collagen gels. Japanese Journal of Cancer Research, 1991, 82(5): 553-558 (doi: 10.1111/j.1349-7006.1991.tb01886.x).

50. Horseman N.D. Prolactin and mammary gland development. Journal of Mammary Gland Biology and Neoplasia, 1999, 4: 79-88 (doi: 10.1023/a:1018708704335).

51. Lemosquet S., Raggio G., Lobley G.E., Rulquin H., Guinard-Flament J., Lapierre H. Wholebody glucose metabolism and mammary energetic nutrient metabolism in lactating dairy cows receiving digestive infusions of casein and propionic acid. Journal of Dairy Science, 2009, 92(12): 6068-6082 (doi: 10.3168/jds.2009-2018).

52. Попкова Н.А. Продуктивность и химический состав молочного сырья коров при использовании иммуномодуляторов. Мат. Межд. науч.-практ. конф., посвященной 75-летию Курганской области «Пути реализации федеральной научно-практической программы развития сельского хозяйства на 2017-2025 годы». Лесниково, 2018: 632-637.

53. Brizhko A.L., Bidchenko S.Yu. Stimulating milk productivity in sows by means of tissue preparations. Visnyk Si'ls'ko-hospodars'koyi Nauky, 1970, 13(10): 100-103.

54. Филатов В.П. Некоторые вопросы тканевой терапии. Офтальмологический журнал, 1946 , 3: 3-6.

55. Buttchereit N., Stamer E., Junge W., Thaller G. Evaluation of lactation curve models fitted for fat: protein ratio of milk and daily energy balance. American Dairy Science Association, 2010, 93(4): 1702-1712 (doi: 10.3168/jds.2009-2198).

56. Митяшова О.С., Гусев И.В., Лебедева И.Ю. Обмен веществ и репродуктивная функция в послеродовой период у коров-первотелок при введении им экстракта плаценты. Сельскохозяйственная биология, 2017, 2: 323-330 (doi: 10.15389/agrobiology.2017.2.323rus).

57. Sami M., Mohri M., Seifl H.A. Effects of dexamethasone and insulin alone or in combination on energy and protein metabolism indicators and milk production in dairy cows in early lactation - a randomized controlled trial. PLOS ONE, 2015, 10(9): e0139276 (doi 10.1371/journal.pone.0139276).

\section{1ФГБНУ Федеральный Алтайский научный центр} агробиотехнологий,

656910 Россия, Алтайский край, г. Барнаул, п. Научный городок, 35,

Поступила в редакцию

e-mail: pushkarev.88-96@mail.ru $₫$, kureninova77@inbox.ru,

shanshin_2012@rambler.ru, uax23@mail.ru,89130847532@mail.ru;

\section{${ }^{2}$ ФГБУ ВО Алтайский государственный аграрный}

университет,

656049 Россия, г. Барнаул, Красноармейский проспект, 98,

e-mail: antonina59-09@mail.ru, o.e.vlasova@yandex.ru,

sve-burceva@yandex.ru 


\title{
METABOLIC STATUS AND MILK PRODUCTIVITY OF COWS INJECTED WITH A TISSUE BIOSTIMULANT DERIVED FROM REINDEER HUSBANDRY WASTE
}

\author{
I.A. Pushkarev ${ }^{\boxplus}$, A.I. Afanasyeva ${ }^{2}$, T.V. Kureninova ${ }^{1}$, N.V. Shanshin ${ }^{1}$, Yu.A. Khaperskiy ${ }^{1}$, \\ O.Ye. Maltseva ${ }^{2}$, S.V. Burtseva ${ }^{2}$, Yu.A. Chekunkova ${ }^{1}$
}

${ }^{1}$ Federal Altai Scientific Centre of Agro-BioTechnologies, 35, Nauchnyy gorodok, Barnaul, 656910 Russia, e-mail pushkarev.88-96@mail.ru ( $₫$ corresponding author), kureninova77@inbox.ru, shanshin_2012@rambler.ru, uax23@mail.ru, 89130847532@mail.ru;

${ }_{2}^{2}$ Altai State Agricultural University, 98, Krasnoarmeisky prospect, Barnaul, 656049 Russia, e-mail antonina59-09@mail.ru, o.e.vlasova@yandex.ru, sve-burceva@yandex.ru

ORCID:

Pushkarev I.A. orcid.org/0000-0003-2078-882X

Afanasyeva A.I. orcid.org/0000-0002-6970-5987

Kureninova T.V. orcid.org/0000-0001-7791-8424

Shanshin N.V. orcid.org/0000-0002-3261-2410

The authors declare no conflict of interests

Received April 12, 2021

Khaperskiy Yu.A. orcid.org/0000-0002-9565-8694

Maltseva O.Ye. orcid.org/0000-0002-0639-4237

Burtseva S.V. orcid.org/0000-0002-0670-9526

Chekunkova Yu.A. orcid.org/0000-0003-0287-8629

doi: 10.15389/agrobiology.2021.4.772eng

\section{Abstract}

The metabolism intensity and pathways during lactation largely determine cow milk production. The use of tissue bio-stimulants optimizes metabolic processes in animal body by activating neurohumoral regulation mechanisms and has a positive effect on lactogenesis and lactopoesis. Tissue biostimulants are derived from various raw materials under various technologies. Therefore, understanding the mode of their action on physiological status and productive qualities of farm animals is relevant. This paper is the first experimental conformation that fourfold administration of the new tissue biostimulant to cows during the dry period and the first 100 days of lactation promotes protein and lipid metabolism in lactating cows. It was proven that the administration of the tissue bio-stimulant according to the developed scheme increases daily milk yields and milk protein and butterfat yields during the first 60 days of lactation. Our goal was to evaluate the effect of the new tissue bio-stimulant derived from reindeer waste on metabolic indices of cows and their milk production. The study was conducted in the herd of Black-Pied cows of the Priobskiy type during dry period and early lactation (the farm of the AO Uchkhoz Prigorodnoye, Barnaul, the Altai Region, 2019). Dry cows at the 3rd lactation were assigned to two groups $(n=10)$ 55-60 days before the expected calving. In the control group, saline solution was injected during the dry period (55-60 days before the expected calving fourfold, $22.5 \mathrm{ml}$ per head two weeks apart) and during the first 100 days of lactation - from day 15 at the same dose and frequency. In the trial group, the tissue bio-stimulant was administered according to the same scheme. The batch of the tissue bio-stimulant (Russian Patent No. 2682641) was obtained from mesenteric lymph nodes and mediastinums, spleen, liver, uteri with 2-3 month old fetuses, and placentae collected under aseptic conditions from healthy animals at slaughtering. Before the experiment and on days 15 and 60 of lactation, blood samples were collected from the tail veins into clot activator tubes. The levels of total blood protein, albumin, cholesterol, triglycerides, and glucose were measured (an automated ChemWell Combi 2910 Analyzer, Awareness Technology Inc., USA), the amount of blood globulins, the albumin to globulin ratio and the cholesterol to triglyceride ratio were calculated. The daily milk yields were recorded on days 15,30 , and 60 of lactation by control milking; the milk yield over 60 days of lactation was calculated. On days 15 and 60 of lactation, the concentrations of protein and butterfat in milk were determined (a MilkoScan FT 120 analyzer, Foss Electric, Denmark), the yields of milk protein and butterfat over 60 days of lactation were calculated according to the common formula. The administration of the tissue bio-stimulant had a promoting effect on metabolism activation and increased the indices of constructive and energy metabolism. The serum levels of total protein, albumin, and cholesterol increased by 3.0-6.4 \% (p<0.01), 9.2-6.9\% (p<0.001), and $18.3-26.0 \%(\mathrm{p}<0.01)$, respectively, albumin to globulin ratio by $9.0-11.1 \%(\mathrm{p}<0.01)$ as compared to the control. On day 60 of lactation vs. day 15 , the total serum protein increased by $9.7 \%(\mathrm{p}<0.001)$ and $6.1 \%(\mathrm{p}<0.001)$ in control group and trial group, respectively, serum globulin by $20.5 \%(\mathrm{p}<0.001)$ and $16.2 \%(\mathrm{p}<0.001)$, and cholesterol by $2.0 \%$ and $8.6 \%(\mathrm{p}<0.01)$. The albumin to globulin ratio decreased by $18.2 \%(\mathrm{p}<0.001)$ and $16.7 \%(\mathrm{p}<0.001)$. In the trial group, milk production for 60 days of lactation increased by $19.3 \%(\mathrm{p}<0.01)$ and the yields of milk protein and butterfat by $26.7 \%(\mathrm{p}<0.05)$ and $22.1 \%(\mathrm{p}<0.05)$.

Keywords: tissue stimulant, cows, metabolism, milk quality, lactation performance. 